\title{
FY21 status report on the Molten Salt Thermal Properties Database (MSTDB) development
}

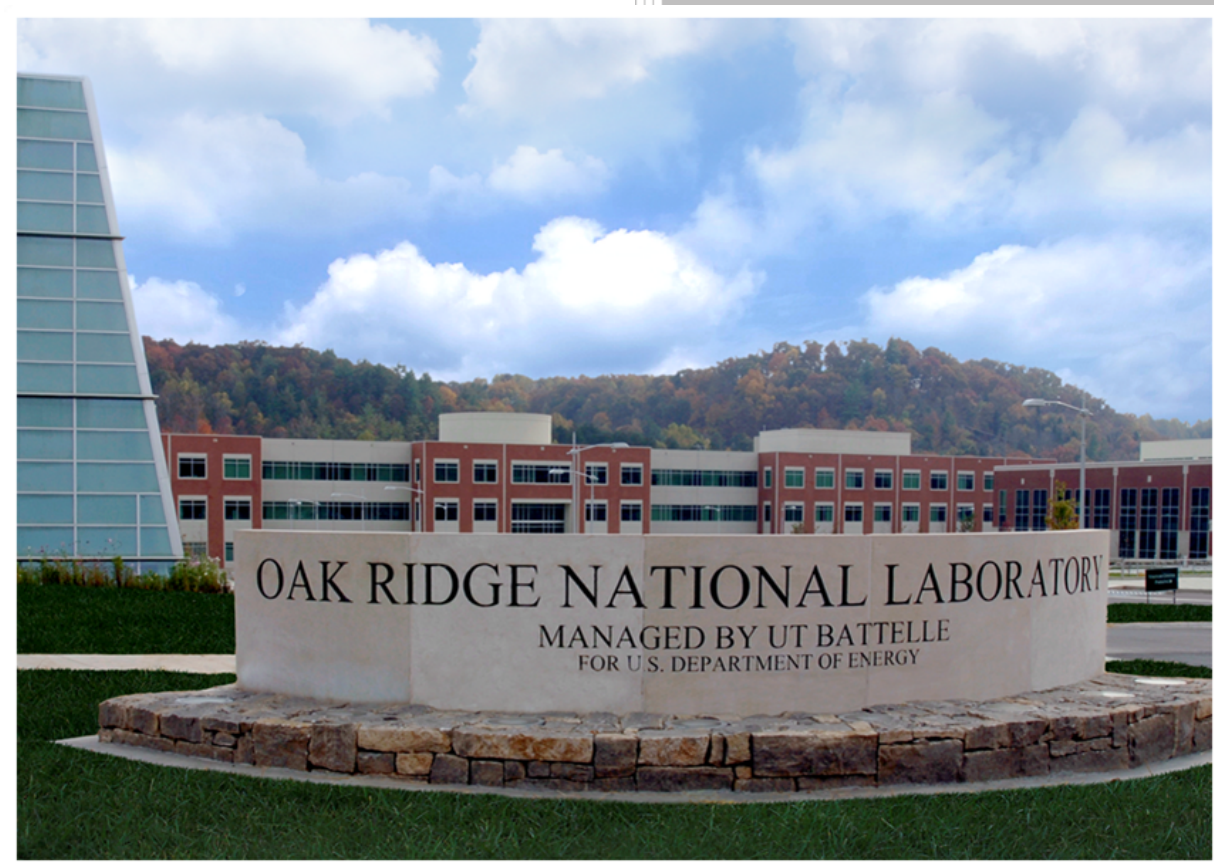

Approved for public release.

C Agca

KE Johnson

JW McMurray

JA Yingling

TM Besmann

Distribution is unlimited.

August 31, 2021 


\title{
DOCUMENT AVAILABILITY
}

Reports produced after January 1, 1996, are generally available free via US Department of Energy (DOE) SciTech Connect.

Website www.osti.gov

Reports produced before January 1, 1996, may be purchased by members of the public from the following source:

\author{
National Technical Information Service \\ 5285 Port Royal Road \\ Springfield, VA 22161 \\ Telephone 703-605-6000 (1-800-553-6847) \\ TDD 703-487-4639 \\ Fax 703-605-6900 \\ E-mail info@ntis.gov \\ Website http://classic.ntis.gov/
}

Reports are available to DOE employees, DOE contractors, Energy Technology Data Exchange representatives, and International Nuclear Information System representatives from the following source:

Office of Scientific and Technical Information

PO Box 62

Oak Ridge, TN 37831

Telephone 865-576-8401

Fax 865-576-5728

E-mail reports@osti.gov

Website http://www.osti.gov/contact.html

This report was prepared as an account of work sponsored by an agency of the United States Government. Neither the United States Government nor any agency thereof, nor any of their employees, makes any warranty, express or implied, or assumes any legal liability or responsibility for the accuracy, completeness, or usefulness of any information, apparatus, product, or process disclosed, or represents that its use would not infringe privately owned rights. Reference herein to any specific commercial product, process, or service by trade name, trademark, manufacturer, or otherwise, does not necessarily constitute or imply its endorsement, recommendation, or favoring by the United States Government or any agency thereof. The views and opinions of authors expressed herein do not necessarily state or reflect those of the United States Government or any agency thereof. 
Department of Energy

Office of Nuclear Energy

Nuclear Energy Advanced Modeling and Simulation Program

FY21 status report on the Molten Salt Thermal Properties Database (MSTDB) development

\author{
Author(s) \\ C Agca \\ KE Johnson \\ JW McMurray \\ JA Yingling \\ TM Besmann
}

Date Published:

August 31, 2021

Prepared by

OAK RIDGE NATIONAL LABORATORY

Oak Ridge, TN 37831-6283

managed by

UT-BATTELLE, LLC

for the

US DEPARTMENT OF ENERGY

under contract DE-AC05-00OR22725 



\section{CONTENTS}

ABSTRACT

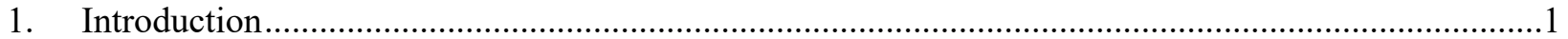

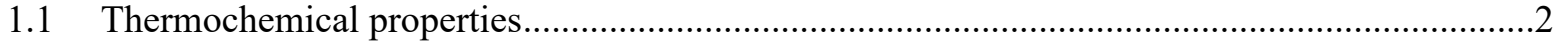

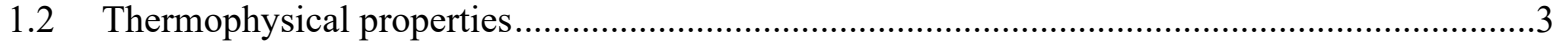

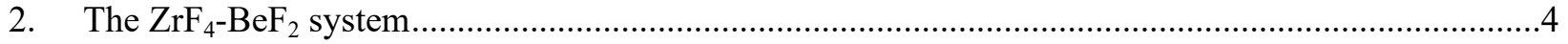

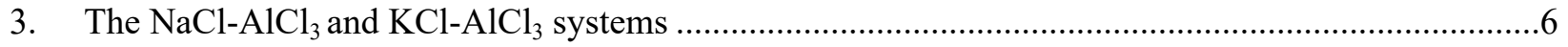

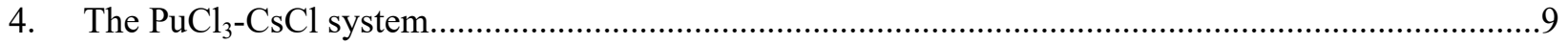

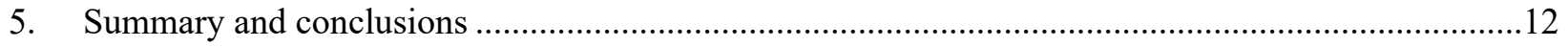

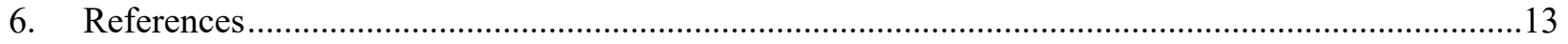




\begin{abstract}
This report describes the thermodynamic assessments for the $\mathrm{ZrF}_{4}-\mathrm{BeF}_{2}, \mathrm{AlCl}_{3}-\mathrm{NaCl}, \mathrm{AlCl}_{3}-\mathrm{KCl}$ and the $\mathrm{PuCl}_{3}-\mathrm{CsCl}$ pseudo-binary subsystems. Calculation results are compared to the inputs used to optimize the adjustable model parameters. The data came from experimental studies reported in the open literature, from the MSR research community, and/or computational results generated within the NEAMS program and from collaborators. The models from the thermodynamic assessment of these salt systems are integrated into the MSTDB-TC (Molten Salt Thermal Properties Database-Thermochemical). A brief description of the companion MSTDB-TP (Molten Salt Thermal Properties Database-Thermophysical) is given along with an overview of the approach for predicting both thermodynamic and thermophysical property behavior of multicomponent systems.
\end{abstract}

\title{
1. Introduction
}

Salt thermal properties are fundamental inputs needed for data-based radio-isotope distribution modeling and simulation of MSRs. As pointed out in the Roadmap for thermal property measurement of Molten Salt Reactor systems [1], it is important to understand the variance in salt properties with composition. This is a challenge due to buildup of products generated from fission, transmutation, and decay but also from corrosion and additives. Previous efforts have used empirical relations to represent density $(\rho)$, viscosity $(v)$, thermal conductivity $(\kappa)$, and specific heat or heat capacity $(\mathrm{Cp})$ as a function of composition and temperature predominately between pure salts [2]. For mixtures relevant to MSRs with continuously evolving elemental inventories, this becomes a Sisyphean task as the compositional degrees of freedom are too large. Fortunately, the NEAMS program is developing the MSTDB. It is a practical path forward for data-based property and phase equilibria estimations of multicomponent salt mixtures derived from relations for the fundamental pseudo-binaries only.

It is well established within the materials thermodynamics community that multicomponent system behavior can be estimated by extrapolation from the lower order subsystems. The unaries and binaries are therefore fundamental. It has been demonstrated that two-body interactions generally dominate [3-5]. The MSTDB is to be populated with pure and pseudo-binary ${ }^{1}$ salts with respect to temperature and composition. To a first approximation, a formalism based on a Redlich-Kister expansion [6], or similar expression [7-10], can be used in the correction for the interactions in binary systems that can be combined for predicting both thermochemical behavior as well as $\rho, v, \kappa$, and $\mathrm{Cp}$ in higher order systems. In this way, populating the MSTDB with pure salt properties, and pseudo-binary mixture properties allows for data-based extrapolation into multicomponent space, i.e., properties of a base salt with fission products.

The property data will be generated experimentally and computationally, e.g., via ab-initio and classical Molecular Dynamics (MD). These raw data are used as inputs for development of the MSTDB by optimizing the adjustable parameters to either a Gibbs energy model or an empirical one for representing $\rho, v, \kappa$, and $\mathrm{Cp}$ in temperature and composition (T-C) space. The MSTDB is subdivided into a thermochemical (MSTDB-TC) and a thermophysical component (MSTDB-TP). This is done because of the fundamental difference in how the two are used in a calculation. A Gibbs Energy Minimizer (GEM) is needed to determine the thermodynamic equilibrium state that yields phase relations and other values like vapor pressure $\left(\mathrm{p}^{*}\right), \mathrm{Cp}^{2}$ and chemical potentials using the MSTDB-TC. The MSTDB-TP, on the

\footnotetext{
${ }^{1}$ Since the end-members are halides, a two salt mixture is a pseudo-binary and the system is properly a ternary.

${ }^{2}$ The specific heat or heat capacity is sometimes considered a thermophysical property. It is a thermodynamic property and can be calculated using Maxwell relations from the Gibbs energy.
} 
other hand, is a simpler additive, deterministic calculation that can be done easily in a spreadsheet software, e.g. Microsoft(C Excel.

\subsection{Thermochemical properties}

The Computer Coupling of Phase Diagrams and Thermochemistry (CALPHAD) method [11] is the accepted approach for thermodynamic modeling and database development within the materials community. The MSTDB-TC uses existing literature, newly generated experimental data primarily from the MSR campaign, and computational derived properties using classical or ab-initio Molecular Dynamics to optimize the adjustable parameters for the models. An accompanying data package documenting the source of every model and/or the raw data used for its continuing development is included [12]. Currently, it accommodates at least 21 elements and models for 87 pseudo-binary (53 fluoride, 34 chloride) and 34 pseudo-ternary (28 fluoride, 6 chloride) and 5 higher order ( 3 fluoride and 2 chloride) molten salt solutions along with 42 solid solutions 165 stoichiometric compounds and 59 gas species (Figure 1). With CALPHAD, the database can be built upon, or extended, to include more elements as more systems are studied. The aim is to include all the impactful elements that will exist during operation of an MSR including system components for alloys that contact the salt to model the thermochemical behavior with burnup including additives and corrosion products. The MSTDB-TC contains the information necessary to compute inputs, e.g., phase equilibria and chemical potentials, for multi-physics codes to predict mass accountancy including microstructure and mass transport in structural materials. This work adds to the existing portfolio of fundamental subsystem assessments to include the $\mathrm{ZrF}_{4}-\mathrm{BeF}_{2}, \mathrm{AlCl}_{3}-\mathrm{NaCl}, \mathrm{AlCl}_{3}-\mathrm{KCl}$ and the $\mathrm{PuCl}_{3}-\mathrm{CsCl}$ pseudo-binaries.

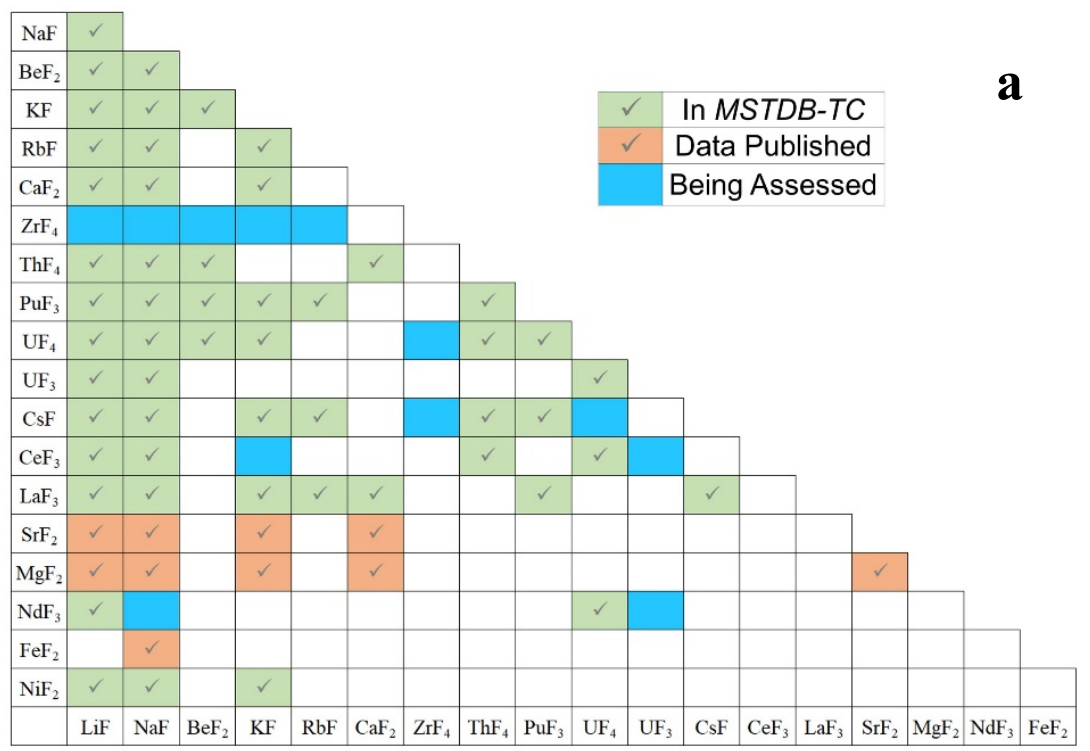




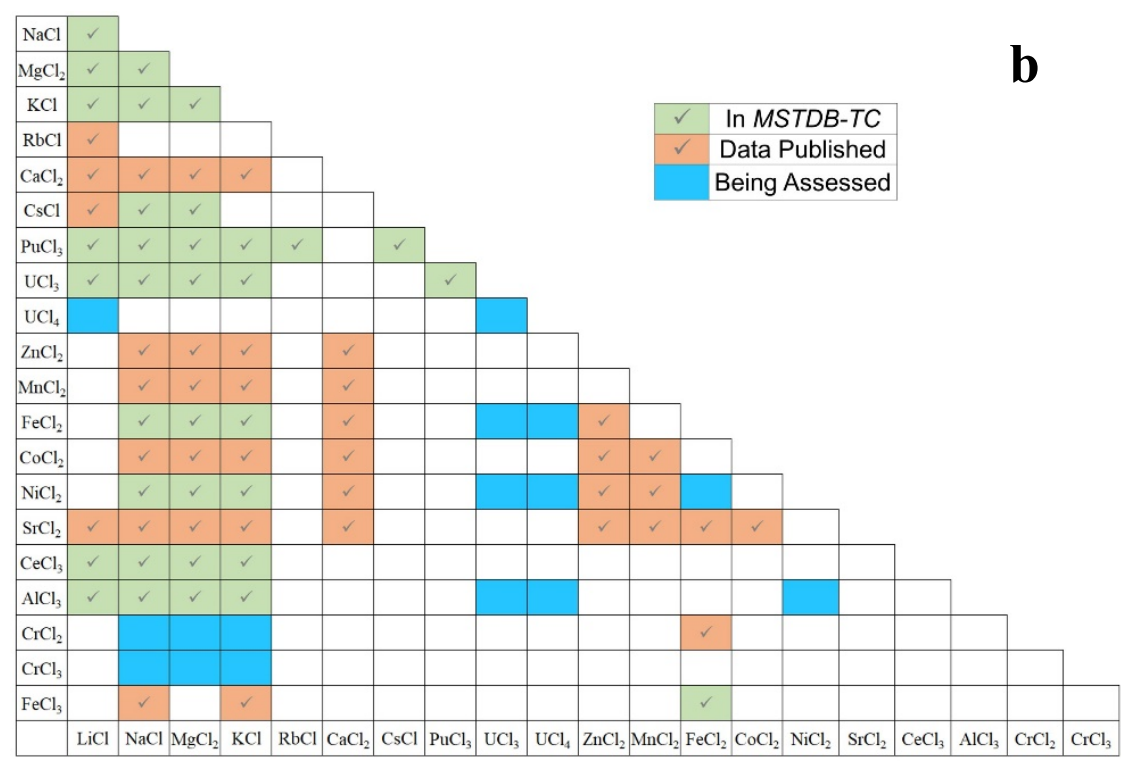

Figure 1. Current status of the MSTDB-TC in a) Fluoride; b) Chloride molten salt systems

The modified quasichemical model (MQM) is considered as the standard for molten salts [13] and is necessary to be consistent with the balance of the systems comprising the MSTDB-TC [14]. The twosublattice MQM can be used to describe the short-range ordering (SRO) in a melt by defining cationcation coordination numbers $\left(Z_{i j}^{i}\right)$ to designate a composition of maximum SRO [15]. The Gibbs energy of mixing at these points are then described in terms of optimized, concentration-independent coefficients $\left(\Delta g_{A B / C l}^{o}\right.$ and $\left.g_{A B / C l}^{i j}\right)$ using Equation 1, where the $g_{A B / C l}^{i j}$ terms may be equal to zero $[13,15,16]$.

$$
\Delta g_{\mathrm{AB} / \mathrm{Cl}}=\Delta g_{A B / C l}^{o}+\sum_{(i+j \geq 1)} g_{A B / C l}^{i j} X^{i} X^{j}
$$

\subsection{Thermophysical properties}

The MSTDB-TP is the thermophysical analogue to MSTDB-TC. It is a collection of empirical models for representing $\rho, v, \kappa$, and $\mathrm{Cp}$ of molten salts as a function of temperature and composition. These are required inputs for thermal hydraulics and mass transport models. Unlike the MSTDB-TC, it does not require a GEM. Models are additive based on a mechanical mixture of the pure salt compound constituents with binary interactions only. In some cases, when available, ternary or higher order interaction parameters may be included. An API (Applied Programming Interface) for standalone material properties predictions and the Saline code for coupling to Multiphysics codes is under development for its use. Currently there are 62 entries. Of them, 27 are pure compounds (14 fluorides and 13 chlorides), 8 pseudo-binary systems ( 1 chloride and 7 fluorides), 10 pseudo-ternaries (all of them fluorides) and 5 pseudo-quaternaries (all of them fluorides).

An example of this for density is given in Figure 2 in NaCl-KCl- $\mathrm{UCl}_{3}$ molten salt system. The RedlichKister model uses pseudo-binary interaction parameters to better represent the densities compared to ideal mixing behavior. This indicates a significant nonideal behavior in this particularpseudo-ternary system caused by the interaction of the molecules. 


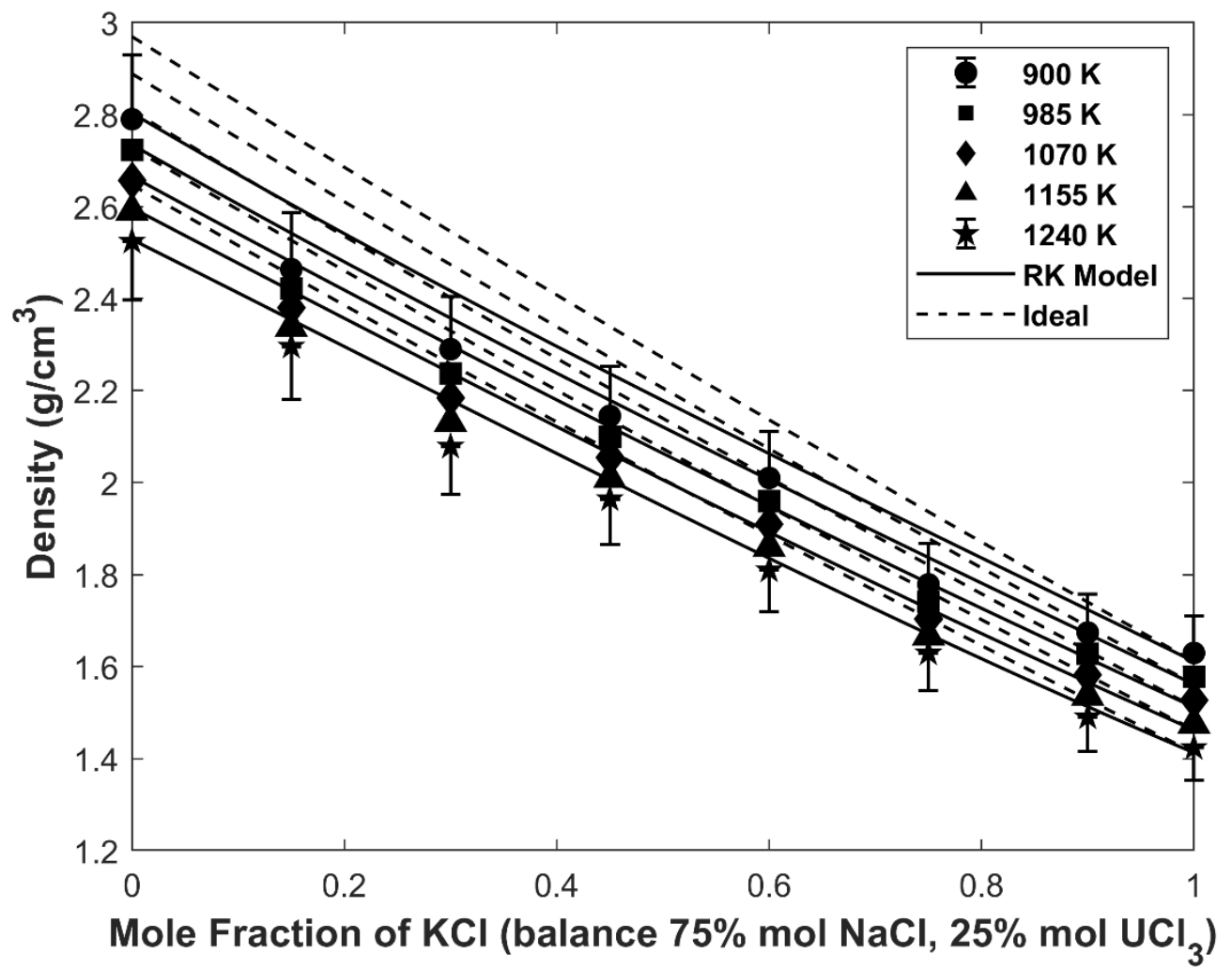

Figure 2. Calculated density for the pseudo-ternary $\mathrm{NaCl}-\mathrm{KCl}-\mathrm{UCl}_{3}$ system extrapolated from the pseudo-binaries.

\section{The $\mathrm{ZrF}_{4}-\mathrm{BeF}_{2}$ system}

The $\mathrm{BeF}_{2}-\mathrm{ZrF}_{4}$ pseudo-binary salt is part of $\mathrm{LiF}-\mathrm{BeF}_{2}-\mathrm{ZrF}_{4}$ pseudo-ternary system which is used as a carrier salt in MSRs [17]. The LiF-BeF ${ }_{2}$ molten salt acts as the solvent matrix for uranium $\left(\mathrm{UF}_{4}\right)$. Zirconium tetrafluoride is added to $\mathrm{LiF}_{-} \mathrm{BeF}_{2}$ solutions up to about 5 molar percent as an oxygen getter [18]. For reactor design and safety, it is important to have accurate thermodynamic models for the $\mathrm{BeF}_{2^{-}}$ $\mathrm{ZrF}_{4}$ system. Having a complete description of the pseudo-binary aids extrapolation into ternary and higher order space [3-5]. Earlier experimental attempts described this pseudo-binary as a single eutectic system with a stoichiometric compound, $\mathrm{BeZrF}_{6}$ [19]. However, a later phase equilibria investigation by Thoma et al. found a miscibility gap in the liquid phase on $\mathrm{BeF}_{2}$ rich-side. They also found that $\mathrm{BeF}_{2}$ and $\mathrm{ZrF}_{4}$ phases do not form solid solution, and no stoichiometric BeZrF 6 compound was observed [20]. Both $\mathrm{ZrF}_{4}$ and $\mathrm{BeF}_{2}$ are glass forming materials [21,22]. However, the coordination chemistry of $\mathrm{BeF}_{2}-\mathrm{ZrF}_{4}$ system has not been experimentally studied.

The $\mathrm{BeF}_{2}-\mathrm{ZrF}_{4}$ system has been thermodynamically modeled using pure endmembers in the solid phase and classical polynomial model in the liquid phase by Benes and Konings [18]. The resulting calculated diagram did not precisely capture the liquidus and differed some from the eutectic both of which were suggested by experimental work of Thoma et al. [20]. In a different salt system, $\mathrm{BeF}_{2}$ liquid phase was modeled using MQM. In the model, the $\mathrm{BeF}_{2}$ liquid consisted of $B e_{I V}^{2+}, B e_{2}^{4+}$, and $\mathrm{F}^{-}$ions which allows for defining two different compositions of maximum short-range ordering in the $\mathrm{BeF}_{2}$ containing solutions. $B e_{I V}^{2+}$ is the 4-coordinated $\mathrm{Be}^{2+}$ cation and $\mathrm{Be}_{2}^{4+}$ is the F-bridged dimerized representation of $\mathrm{Be}^{2+}[23]$. 
The assessment continues in progress using the CALPHAD method to describe the $\mathrm{BeF}_{2}-\mathrm{ZrF}_{4}$ pseudobinary system. Available experimental information in this system was collected and reviewed critically for the optimization of the thermodynamic parameters. Optimization of parameters was performed using FactSage 8.1 [24,25] software using the trial-and-error methodology. Temperature-composition phase diagram was used as means to define the goodness of fit in accordance with the literature data.

Solid phases were described as pure compounds with no mixing. There are two endmembers in the solid phase: $\mathrm{BeF}_{2}$ and $\mathrm{ZrF}_{4}$. Beryllium difluoride has two stable polymorphs. One is low temperature quartz $(\alpha)$ and the other is high temperature cristobalite $(\beta)$ [26,27]. Another glassy form of $\mathrm{BeF}_{2}$ exists below 500 $\mathrm{K} . \mathrm{MQM}$ is appropriate for describing the liquid phase in the molten salt systems $[13,28,29]$. The two sublattice MQM describes the short-range ordering (SRO) in a melt by defining cation-cation coordination numbers $\left(Z_{i j}^{i}\right)$ which designates a composition with maximum SRO [15].

Phase diagram features such as eutectic or congruent melting points with large temperature differences or liquid-liquid miscibility gap with a neighboring steep liquidus changes are difficult to model within desired accuracy requirements using single maximum SRO scheme. Several temperature dependent interaction parameters can be used to mitigate this, but complicate extrapolation into multicomponent salt systems [18]. Therefore, a change in the cation components of the two sublattice model can be useful as outlined by Robelin et al. [30].

Table 1 shows the thermodynamic properties for the compounds in the $\mathrm{BeF}_{2}-\mathrm{ZrF}_{4}$ system. The $\mathrm{BeF}_{2}$ solid phases are represented by $S_{1}$ (low quartz type $-\alpha$ ) and $S_{2}$ (cristobalite type $-\beta$ ). All the $B_{e} F_{2}$ compound thermodynamic properties were taken from JANAF tables [31]. The $\mathrm{ZrF}_{4}$ solid and liquid phase data were taken from Benes et al. [18], whereas the gas phase data come from SGPS [24,25,32]. The liquid $\mathrm{Be}_{2} \mathrm{~F}_{4}$ dimer Gibbs energy was calculated with Equation 2 [23].

$$
G_{B e_{2} F_{4}}^{o}=2 G_{B e F_{2}}^{o}
$$

The $\mathrm{BeF}_{2}-\mathrm{ZrF}_{4}$ phase diagram without the gas phase is given in Figure 3. Thoma et al. [20] reported phase equilibrium temperatures shown in discrete symbols and estimated the phase diagram (shown with dashed line). Our tentative phase diagram establishes the miscibility gap and agrees with the liquidus in the $\mathrm{ZrF}_{4}-$ rich compositions reported in Thoma et al. [20]. However, it does not overlap with the eutectic composition and peritectic on the $\mathrm{BeF}_{2}$-rich side that are calculated by Benes et al. [18]. Further optimizations are currently in place to mitigate these differences. 
Table 1. Thermodynamic properties of compounds for $\mathrm{BeF}_{2}-\mathrm{ZrF}_{4}$ pseudo binary system

\begin{tabular}{|c|c|c|c|c|c|}
\hline Compound & $\begin{array}{l}\text { Temperature } \\
\text { Range (K) }\end{array}$ & $\begin{array}{c}\Delta_{f} H^{0} \\
(298.15 \mathrm{~K}) \\
\text { J.mol }^{-1}\end{array}$ & $\begin{array}{c}\Delta_{f} S^{\theta} \\
(298.15 \mathrm{~K}) \\
\text { J.mol }^{-1} \cdot \mathrm{K}^{-1}\end{array}$ & 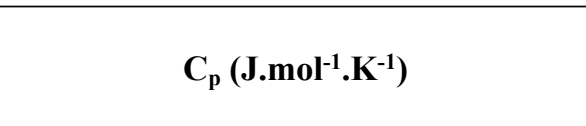 & Source \\
\hline $\begin{array}{cc}\mathrm{BeF}_{2} & \mathrm{~S}_{1} \\
& \mathrm{~S}_{2} \\
& \mathrm{~L}\end{array}$ & $\begin{array}{l}298.15-500 \\
500-1300 \\
298.15-1300 \\
298.15-2000 \\
298.15-1000 \\
1000-6000\end{array}$ & $\begin{array}{l}-1026800.0 \\
-1025796.8 \\
-1021767.3 \\
-795708.6\end{array}$ & $\begin{array}{l}53.3540 \\
55.2530 \\
60.5824 \\
228.279\end{array}$ & $\begin{array}{l}-9.04528+0.161019 \mathrm{~T}+1145921.6 \mathrm{~T}^{-2} \\
47.3630+0.0334717 \mathrm{~T} \\
47.3630+0.0334717 \mathrm{~T} \\
-188.684+2831825 \mathrm{~T}^{-2}-74606.1 \mathrm{~T}^{-1}+ \\
4.35046 \mathrm{~T}^{0.5}+6593.35 \mathrm{~T}^{-0.5} \\
68.0076+0.00104376 \mathrm{~T}+790439 \mathrm{~T}^{-2}+ \\
-9008.12 \mathrm{~T}^{-1} \\
61.5845+-1455261 \mathrm{~T}^{-2}+-5173.85 \mathrm{~T}^{-1}+ \\
119.876 \mathrm{~T}^{-0.5}\end{array}$ & [31] \\
\hline $\begin{array}{l}\mathrm{S} \\
\mathrm{L} \\
\mathrm{G}\end{array}$ & $\begin{array}{l}298.15-6000 \\
298.15-6000 \\
298.15-900 \\
900-6000\end{array}$ & $\begin{array}{l}-1911300.6 \\
-1844349.7 \\
-1669506.0\end{array}$ & $\begin{array}{l}104.650 \\
157.012 \\
322.875\end{array}$ & $\begin{array}{l}115.61+0.0205 \mathrm{~T}-1600510 \mathrm{~T}^{-2} \\
123.6 \\
93.7777+0.0246254 \mathrm{~T}-1112192 \mathrm{~T}^{-2}- \\
1.19878 .10^{-5} \mathrm{~T}^{2} \\
107.953+5.26574 .10^{-5} \mathrm{~T}-2544208 \mathrm{~T}^{-2} \\
-5.37049 .10^{-9}\end{array}$ & $\begin{array}{l}{[18]} \\
{[18]} \\
\text { [32]SGPS } \\
\text { [32]SGPS }\end{array}$ \\
\hline $\mathrm{Be}_{2} \mathrm{~F}_{4}$ & $298.15-2000$ & -2043534.7 & 121.165 & $\begin{array}{l}-377.368+5663649 \mathrm{~T}^{-2}-149212.3 \mathrm{~T}^{-1}+ \\
8.70093 \mathrm{~T}^{0.5}+13186.7 \mathrm{~T}^{-0.5}\end{array}$ & [23] \\
\hline
\end{tabular}

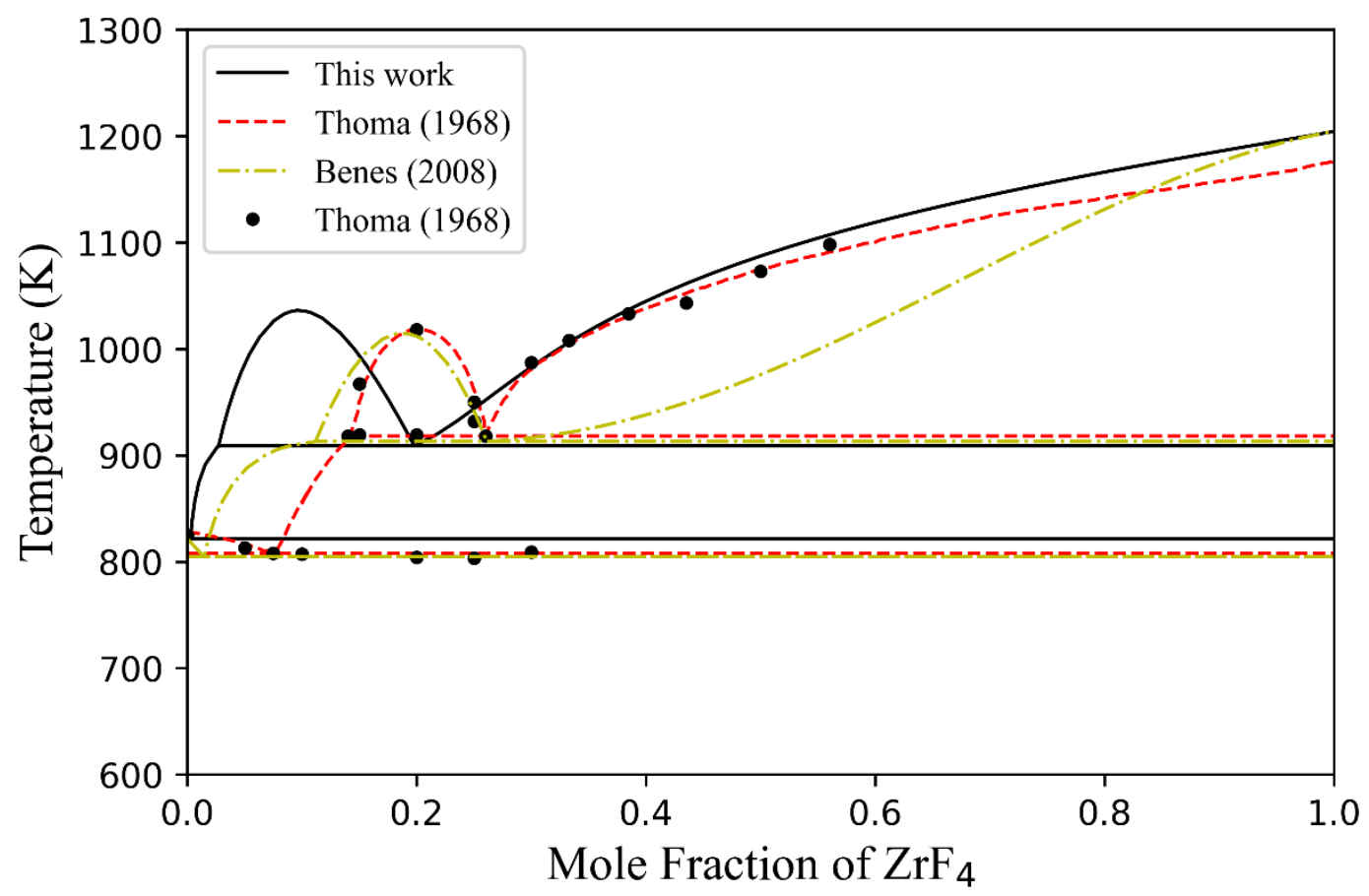

Figure 1. $\mathrm{BeF}_{2}-\mathrm{ZrF}_{4}$ pseudo binary phase diagram.

\section{The $\mathrm{NaCl}-\mathrm{AlCl}_{3}$ and $\mathrm{KCl}-\mathrm{AlCl}_{3}$ systems}

The models for $\mathrm{NaCl}-\mathrm{AlCl}_{3}$ and $\mathrm{KCl}-\mathrm{AlCl}_{3}$ psuedo-binaries are based on the work of Robelin et al. [30] who fully assessed the systems, and no alternative or more recent information, including experimental 
data, are available. The extensive assessment and validation of Robelin et al. [30] however, suggest no further assessment is needed. A general summary of the models follows, with more detail found in the original report.

As with the $\mathrm{BeF}_{2}-\mathrm{ZrF}_{4}$ system, the melt is described using the MQM. The end-members for alkali elements are the simple $\mathrm{NaCl}$ and $\mathrm{KCl}$, however, appropriate treatment of the $\mathrm{AlCl}_{3}$ endmember requires use of two aluminum-containing components, the monomer, $\mathrm{Al}^{3+}$, and a dimer, $\mathrm{Al}_{2}{ }^{6+}$. These correspond to the complex anions $\mathrm{AlCl}_{4}{ }^{-}$and $\mathrm{Al}_{2} \mathrm{Cl}_{7}{ }_{7}^{-}$respectively, whose inclusion is necessary to accommodate the variable second nearest-neighbor ( $\mathrm{SNN}$ ) coordination numbers necessary to reproduce behavior. The anions associate such that SNN coordination maximizes short-range order (SRO) near the composition of the compound $\mathrm{AAlCl}_{4}(\mathrm{~A}=\mathrm{Na}, \mathrm{K})$, an $\mathrm{AlCl}_{3}$ mole fraction of $50 \%\left(\mathrm{x}_{\mathrm{AlCl}}=0.5\right)$. The lowest melting eutectic composition occurs near $\mathrm{AAl}_{2} \mathrm{Cl}_{7}\left(\mathrm{x}_{\mathrm{AlCl} 3}=0.66\right)$.

The extent of SRO near the complex anion compositions is evident in the pseudobinary phase diagrams for the $\mathrm{ACl}-\mathrm{AlCl}_{3}$ systems shown in Figures 4 and 5. In each case a deep eutectic is formed near $\mathrm{x}_{\mathrm{AlCl} 3}=0.5$ composition with a second eutectic occurring near $x_{\mathrm{AlCl} 3}=0.66$. These eutectics were calculated to be $155.2^{\circ} \mathrm{C}$ at $x_{\mathrm{AlCl}}=0.497$ and $108.7^{\circ} \mathrm{C}$ at $x_{\mathrm{AlCl}}=0.612$ for $\mathrm{NaCl}-\mathrm{AlCl}_{3}$ and $241.6^{\circ} \mathrm{C}$ at $x_{\mathrm{AlCl} 3}=0.4864$ and $130.1^{\circ} \mathrm{C}$ at $x_{\mathrm{AlCl} 3}=0.6550$ for $\mathrm{KCl}-\mathrm{AlCl}_{3}$. The phase diagrams computed from the Gibbs energy functions provided to $M S T D B-T C$ reproduce those of Robelin et al. [30].

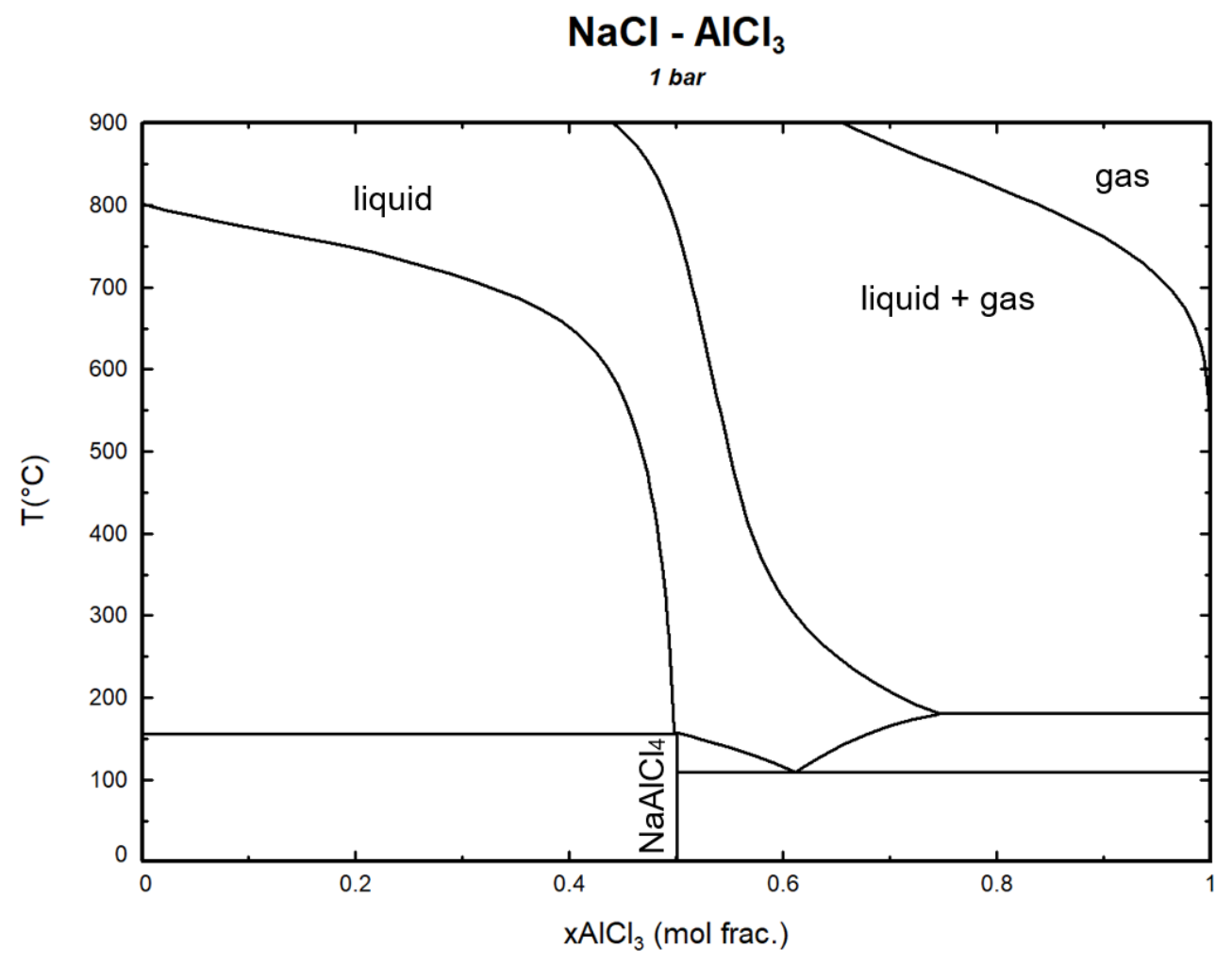

Figure 4. MSTDB-TC computed phase diagram for the $\mathrm{NaCl}-\mathrm{AlCl}_{3}$ system. 


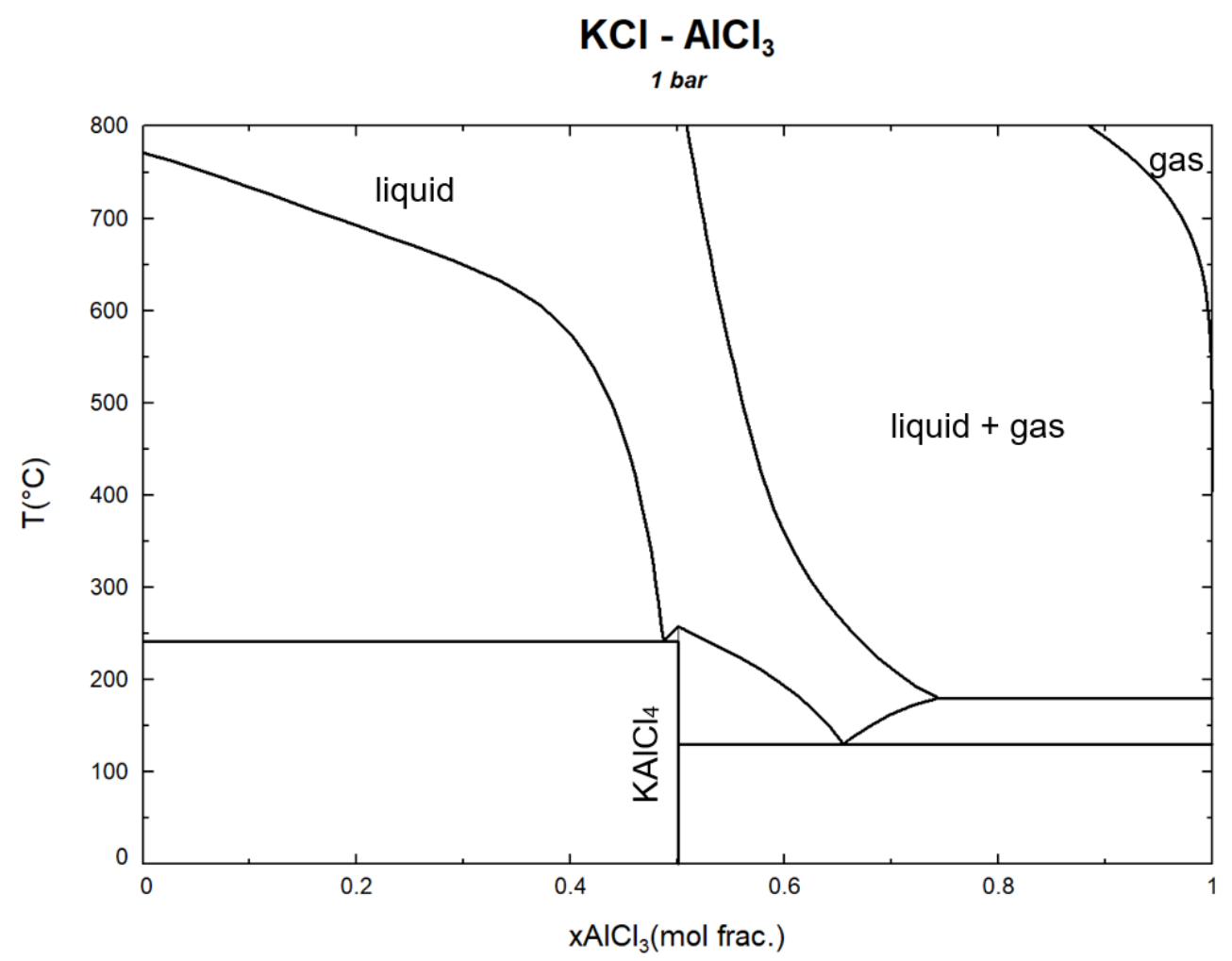

Figure 5. MSTDB-TC computed phase diagram for the $\mathrm{KCl}-\mathrm{AlCl}_{3}$ system.

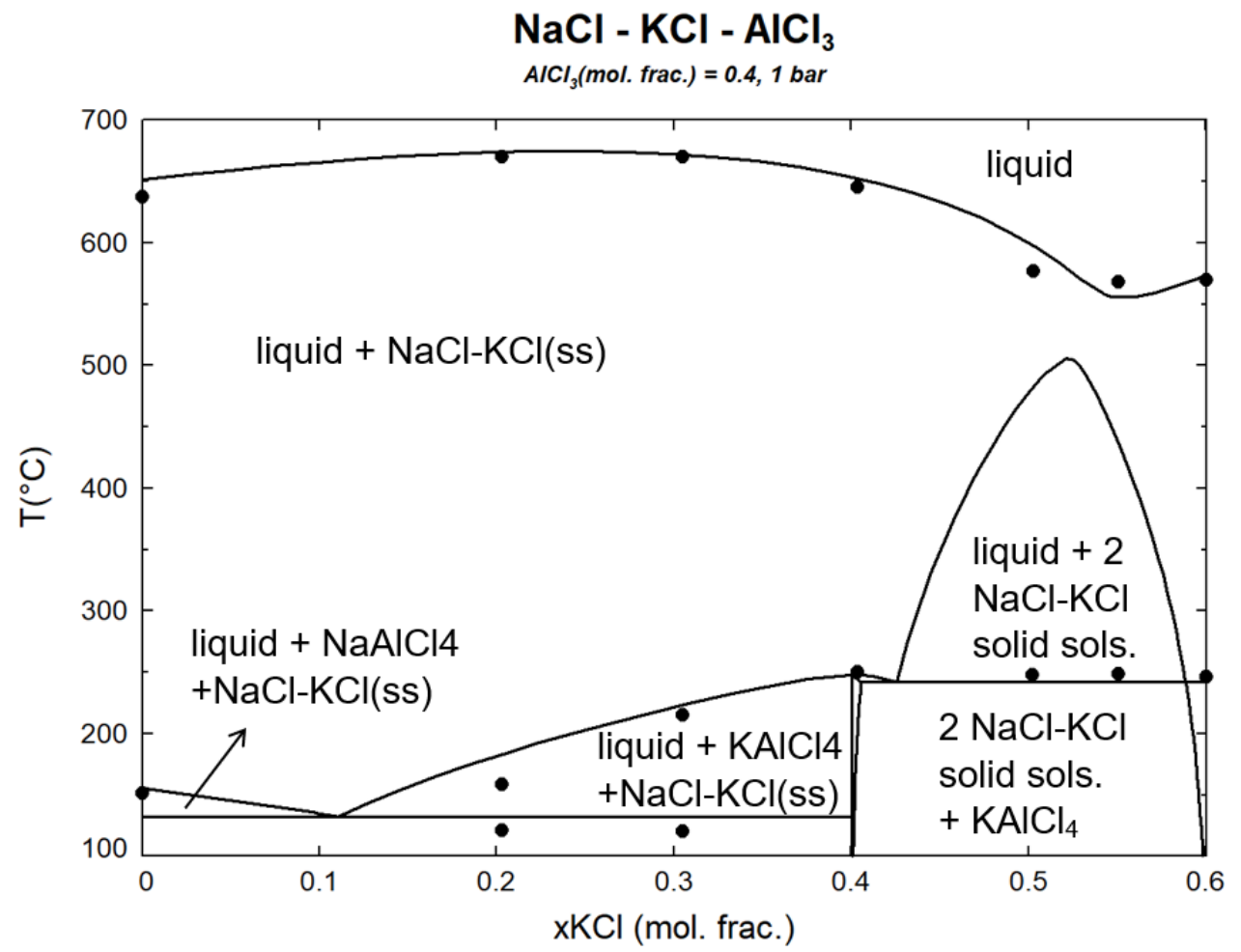

Figure 6. Pseudoternary isopleth at constant $40 \mathrm{~mol} \% \mathrm{AlCl}_{3}$. Experimental data points from Fischer and Simon [33] 
As seen in Figure 6, additional calculations determining various liquidus projections also reproduced those of Robelin et al. [30], and the experimental phase equilibrium data from Fischer and Simon [33] as well. The completeness of the model is notable and further refinement through added experimentation is not needed at present. In sum, the current effort's investigation of the $\mathrm{Na}-\mathrm{K}-\mathrm{Al} / / \mathrm{Cl}$ system based on the extensive assessment of Robelin et al. [30] and the resultant capability to reproduce the phase equilibria has allowed inclusion of the system Gibbs energy functions from that work in MSTDB-TC without requiring further experiments or evaluations.

\section{The $\mathrm{PuCl}_{3}-\mathrm{CsCl}$ system}

The $\mathrm{PuCl}_{3}$ liquid solution was modeled as a combination of the $\mathrm{Pu}^{3+}, \mathrm{Pu}_{2}^{6+}$, and $\mathrm{Cl}^{-}$ions, resulting in the $\mathrm{PuCl}_{3}$ and $\mathrm{Pu}_{2} \mathrm{Cl}_{6}$ endmembers, with $\mathrm{Pu}_{2} \mathrm{Cl}_{6}$ dominating at high concentrations of $\mathrm{PuCl}_{3}$. The hypothetical $\mathrm{Pu}_{2} \mathrm{Cl}_{6}$ "dimer" allowed for the establishment of two points of maximum SRO in the pseudobinary phase diagram. This gives more control over the fit of the liquid solution in order to accurately portray the high congruent melting point of $\mathrm{Cs}_{3} \mathrm{PuCl}_{6}$ and at the same time, represent the deep eutectic point expected at a $\mathrm{PuCl}_{3}$ mole fraction of 0.47 [34]. Maximum SRO was specified to occur at the compositions corresponding to $\mathrm{Cs}_{3} \mathrm{PuCl}_{6}$ and $\mathrm{CsPuCl}_{4}$ compositions using a method previously established by Robelin and Chartrand [23] to model the complex $\mathrm{BeF}_{2}$ and $\mathrm{AlF}_{3}$ liquids in the pseudobinary and higher order systems.

The formation enthalpy and entropy of $\mathrm{Cs}_{3} \mathrm{PuCl}_{6}$ and $\mathrm{CsPu}_{2} \mathrm{Cl}_{7}$ line compounds have never been directly measured but were estimated through phase diagram optimization by Foltyn et al. [35] and by Williamson and Kleinschmidt [36] using experimentally-derived $\mathrm{CsCl}$ sublimation vapor pressure data. However, these works disagree significantly with one another. Furthermore, neither resulted in $\mathrm{Cs}_{3} \mathrm{PuCl}_{6}$ and $\mathrm{CsPu}_{2} \mathrm{Cl}_{7}$ phase stability. Equilibrium calculations using formation entropy and enthalpy values derived from the published sublimation data by Lemire et al. [37] values produced stable line compounds. Those are used as starting values for further optimization in this work.

The thermodynamic values of $\mathrm{Cs}_{3} \mathrm{PuCl}_{6}$ and $\mathrm{CsPu}_{2} \mathrm{Cl}_{7}$ compounds used to calculate the final phase diagram were optimized from those suggested by Lemire et al. [37] in order to maintain stability with the inclusion of the liquid. A polymorphic transition of $\mathrm{Cs}_{3} \mathrm{PuCl}_{6}$ has been experimentally observed to occur at $410^{\circ} \mathrm{C}$ [34], but the enthalpy and entropy associated with this transition has never been measured or estimated [35-38]. Initial thermodynamic values of high temperature $\mathrm{Cs}_{3} \mathrm{PuCl}_{6}$ were estimated from Lemire et al. [37] and optimized to reproduce the $410^{\circ} \mathrm{C}$ transformation. Thermodynamic properties for all compound species of the system are collected in Table 2.

Table 2. Thermodynamic data for compound species

\begin{tabular}{|c|c|c|c|c|c|c|}
\hline \multicolumn{2}{|c|}{ Compound } & \multirow{2}{*}{$\begin{array}{c}\begin{array}{c}\text { Temperature } \\
\text { Range (K) }\end{array} \\
298.15-2000\end{array}$} & \multirow{2}{*}{$\begin{array}{c}\Delta \boldsymbol{H}^{o}(\mathbf{2 9 8 . 1 5}) \\
\mathbf{J}^{-\mathbf{m o l}^{-1}} \\
-442,834.6\end{array}$} & \multirow{2}{*}{$\begin{array}{c}S^{o}(\mathbf{2 9 8 . 1 5}) \\
\mathbf{J}^{-K^{-1} \cdot \mathbf{m o l}^{-1}} \\
101.1817\end{array}$} & \multirow{2}{*}{$\begin{array}{l}C_{p}=\mathbf{a}+\mathbf{b} \boldsymbol{T}+\mathbf{c} \boldsymbol{T}^{2}+\boldsymbol{d} \mathbf{T}^{-2}+\mathbf{e} \boldsymbol{T}^{-0.5} \mathbf{J} \cdot \mathbf{K}^{-} \\
{ }^{1 \cdot} \cdot \mathbf{m o l}^{-1}\end{array}$} & \multirow{2}{*}{$\frac{\text { Source }}{[39]}$} \\
\hline $\mathrm{CsCl}$ & $\mathrm{S}_{1}$ & & & & & \\
\hline \multirow{6}{*}{$\mathrm{PuCl}_{3}$} & $\mathrm{~S}_{2}$ & $298.15-1500$ & $-441,267.3$ & & $59.7308+0.004937(T / \mathrm{K})$ & [39] \\
\hline & $\mathrm{L}$ & 150 & & & 77.404 & [39] \\
\hline & G & 298.1 & & & $22+0.001067(T / \mathrm{K})$ & [39] \\
\hline & $\mathrm{S}$ & $298.15-1500$ & $-959,600.0$ & 161.4000 & $91.412+0.037160(T / \mathrm{K})-27400(T / \mathrm{K})^{-2}$ & [40] \\
\hline & $\mathrm{L}$ & $298.15-2000$ & $-846,016.0$ & 170.4630 & 144 & \multirow{2}{*}{$\begin{array}{l}\text { This work } \\
\text { [41] }\end{array}$} \\
\hline & G & $298.15-2000$ & $-647,400.0$ & 368.6200 & $\begin{array}{l}77.103+0.012997(T / \mathrm{K})-4.3125 \cdot 10^{-6}(T / \mathrm{K})^{2} \\
-188730(T / \mathrm{K})^{-2}\end{array}$ & \\
\hline $\mathrm{Pu}_{2} \mathrm{Cl}_{6}$ & $\mathrm{~L}$ & 29 & & & 288 & [40] \\
\hline \multirow[t]{2}{*}{$\mathrm{Cs}_{3} \mathrm{PuCl}_{6}$} & $\mathrm{~S}_{1}$ & $298.15-1500$ & $-2,380,842.2$ & 455.0034 & $257.0+0.034608(T / \mathrm{K})-739946.3(T / \mathrm{K})^{-2}$ & This work \\
\hline & $\mathrm{S}_{2}$ & $298.15-1500$ & $-2,380,004.1$ & 445.6156 & $205.1+0.259515 T / \mathrm{K})-744082.3(T / \mathrm{K})^{-2}$ & This work \\
\hline $\mathrm{CsPu}_{2} \mathrm{Cl}_{7}$ & $\mathrm{~S}$ & $298.15-1500$ & $-2,389,550.7$ & 433.2339 & $272.2+0.068647(T / \mathrm{K})+162762.5(T / \mathrm{K})^{-2}$ & This work \\
\hline
\end{tabular}


Robelin and Chartrand [23] found that the dimer is the dominant endmember in the $\mathrm{BeF}_{2}-\mathrm{NaF}$ system that was modeled in a similar fashion. Therefore, the $\mathrm{Pu}_{2} \mathrm{Cl}_{6}$ dimer was assigned to have twice the molar Gibbs energy of the literature value for the pure $\mathrm{PuCl}_{3}$ melt [40]. To maintain the melting point of $\mathrm{PuCl}_{3}$, the Gibbs energy of the monomer and dimer mixture must also be as close as possible to that of the pure $\mathrm{PuCl}_{3}$. The Gibbs energy for the $\mathrm{PuCl}_{3}$ melt reduces to the regular solution model in the absence of $\mathrm{CsCl}$ according to Equation 3.

$$
G_{\mathrm{PuCl}_{3}}^{l i t}\left(T_{m}\right)=x_{\mathrm{PuCl}_{3}} G_{\mathrm{PuCl}_{3}}^{o}+x_{\mathrm{Pu}_{2} \mathrm{Cl}_{6}} G_{\mathrm{Pu}_{2} \mathrm{Cl}_{6}}^{o}+x_{\mathrm{PuCl}_{3}} R T \ln x_{\mathrm{PuCl}_{3}}+x_{\mathrm{Pu}_{2} \mathrm{Cl}_{6}} R T \ln x_{\mathrm{Pu}_{2} \mathrm{Cl}_{6}}
$$

The adjustable parameters for the Gibbs energy of the monomer, given by Equation 4, were then optimized to reproduce the Gibbs energy of $\mathrm{PuCl}_{3}$ from literature [40] at the melting point while simultaneously reproducing the phase equilibria in the $\mathrm{PuCl}_{3}-\mathrm{CsCl}$ system.

$$
G_{\mathrm{PuCl}_{3}}^{o}=0.5 G_{\mathrm{Pu}_{2} \mathrm{Cl}_{6}}^{o}+A+B T
$$

The optimized values for the coefficients, $A$ and $B$, are $85,100 \mathrm{~J} \cdot \mathrm{mol}^{-1}$ and $0 \mathrm{~J} \cdot \mathrm{mol}^{-1}$, respectively. In the absence of $\mathrm{CsCl}$, the $\mathrm{PuCl}_{3}$ liquid solution, composed of a mixture of monomers and dimers, was calculated to be $99.99 \mathrm{~mol} \% \mathrm{Pu}_{2} \mathrm{Cl}_{6}$, consistent with observations made by Robelin and Chartrand [23] for the $\mathrm{BeF}_{2}-\mathrm{NaF}$ system. At concentrations of $\mathrm{CsCl}$ higher than $75 \mathrm{~mol} \%$, the $\mathrm{PuCl}_{3}$ monomer is the major plutonium species present in the liquid.

Experimental phase transition data from Benz and Douglass [34] and calculated mixing enthalpy values were used to model the Gibbs energy of the $\mathrm{CsCl}_{\mathrm{PuCl}}$ liquid. The chosen cation-cation coordination numbers for the $\mathrm{CsCl}-\mathrm{PuCl}_{3}$ liquid model are listed in Table 3. The coordination numbers were chosen to establish maximum SRO at the $\mathrm{Cs}_{3} \mathrm{PuCl}_{6}$ and $\mathrm{CsPucl}_{4}$ concentrations, allowing the congruent melting point of $\mathrm{Cs}_{3} \mathrm{PuCl}_{6}$ and the eutectic point at $0.47 \mathrm{PuCl}_{3}$ mole fraction composition, respectively, to be fit independent of one another. The optimized excess Gibbs energy for the two regions of maximum SRO are represented in Equations 5 and 6.

$$
\begin{aligned}
& \Delta g_{\mathrm{CsPu}_{\mathrm{III}} / \mathrm{Cl}}=-56,268.48 \mathrm{~J} \cdot \mathrm{mol}^{-1} \\
& \Delta g_{\mathrm{CsPu}_{2} / \mathrm{Cl}}=-31,789.91-22,309.37 X_{\mathrm{CsCl}}-15,266.21 X_{\mathrm{Pu}_{2} \mathrm{Cl}_{6}} \mathrm{~J} \cdot \mathrm{mol}^{-1}
\end{aligned}
$$

\begin{tabular}{llll}
\multicolumn{5}{c}{ Table 3. Cation-cation coordination num } \\
\hline $\mathrm{A}$ & $\mathrm{B}$ & $\mathrm{Z}_{\mathrm{AB} / \mathrm{Cl}}^{\mathrm{A}}$ & $\mathrm{Z}_{\mathrm{AB} / \mathrm{Cl}}^{\mathrm{B}}$ \\
\hline $\mathrm{Cs}$ & $\mathrm{Cs}$ & 6 & 6 \\
$\mathrm{Pu}$ & $\mathrm{Pu}$ & 6 & 6 \\
$\mathrm{Pu}_{2}$ & $\mathrm{Pu}_{2}$ & 6 & 6 \\
$\mathrm{Cs}$ & $\mathrm{Pu}$ & 2 & 6 \\
$\mathrm{Cs}$ & $\mathrm{Pu}_{2}$ & 3 & 6 \\
\hline
\end{tabular}

The optimized phase diagram is shown in Figure 7 and agrees well with the plotted phase change data from Benz and Douglass [34]. All calculated eutectic temperatures matched those previously determined [34] within $\pm 0.0008 \%$. The eutectic points predicted from the MQM are $0.0834,0.4657$, and 0.7118 $\mathrm{PuCl}_{3}$ mole fractions, values comparable to the $0.10,0.47$, and 0.70 proposed by Benz and Douglass [34]. Previous modeling using a Redlich-Kister polynomial calculated lower than expected temperatures for the $\mathrm{Cs}_{3} \mathrm{PuCl}_{6}$ congruent melting point and eutectics with low temperatures and compositions [35]. The enthalpy of mixing calculated at $873.85^{\circ} \mathrm{C}$ shows good agreement with an unpublished theoretical work as can be seen in Figure 8. 


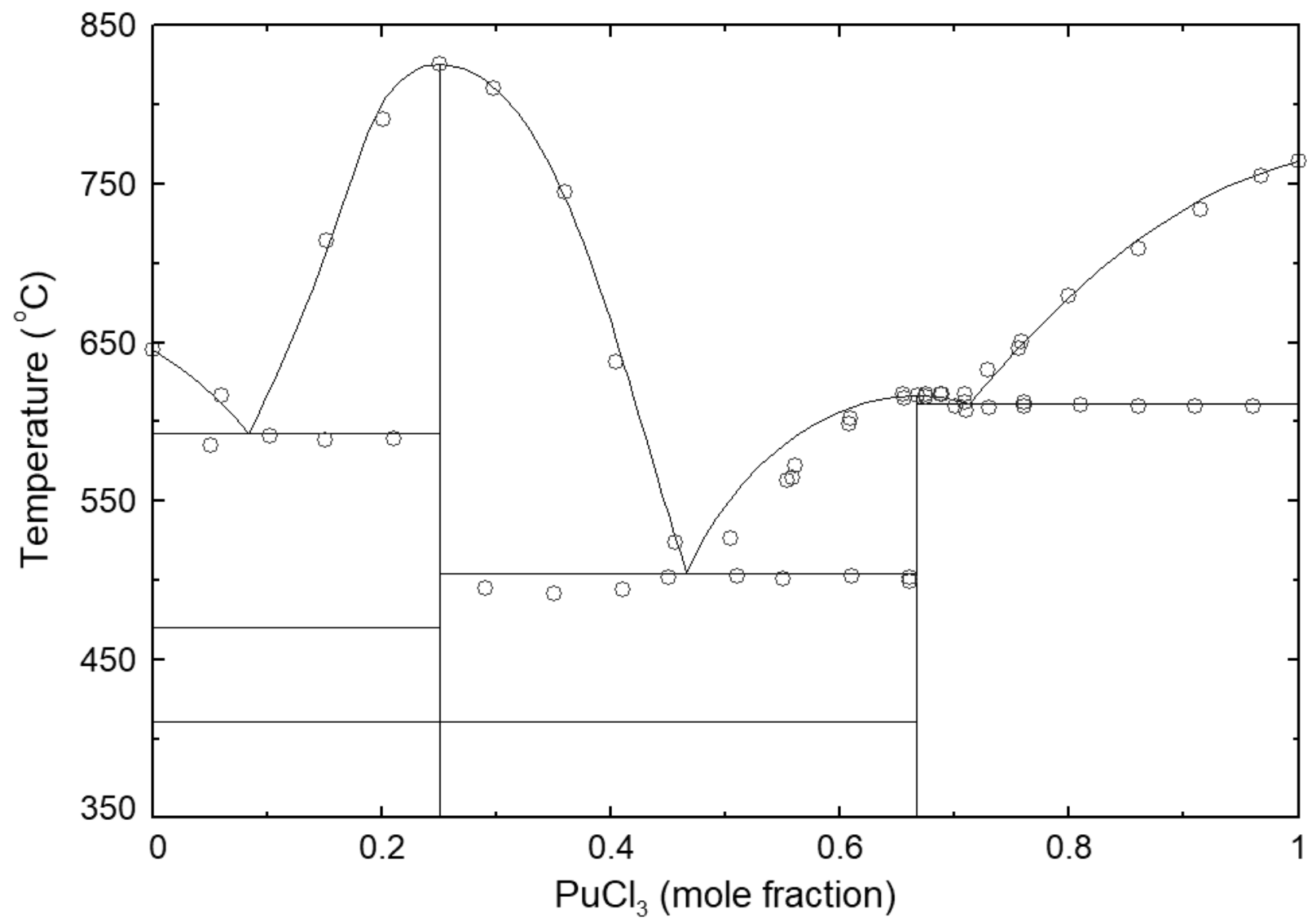

Figure 7. Calculated $\mathrm{CsCl}-\mathrm{PuCl} 3$ phase diagram. Experimental data from Benz and Douglass [34]. 


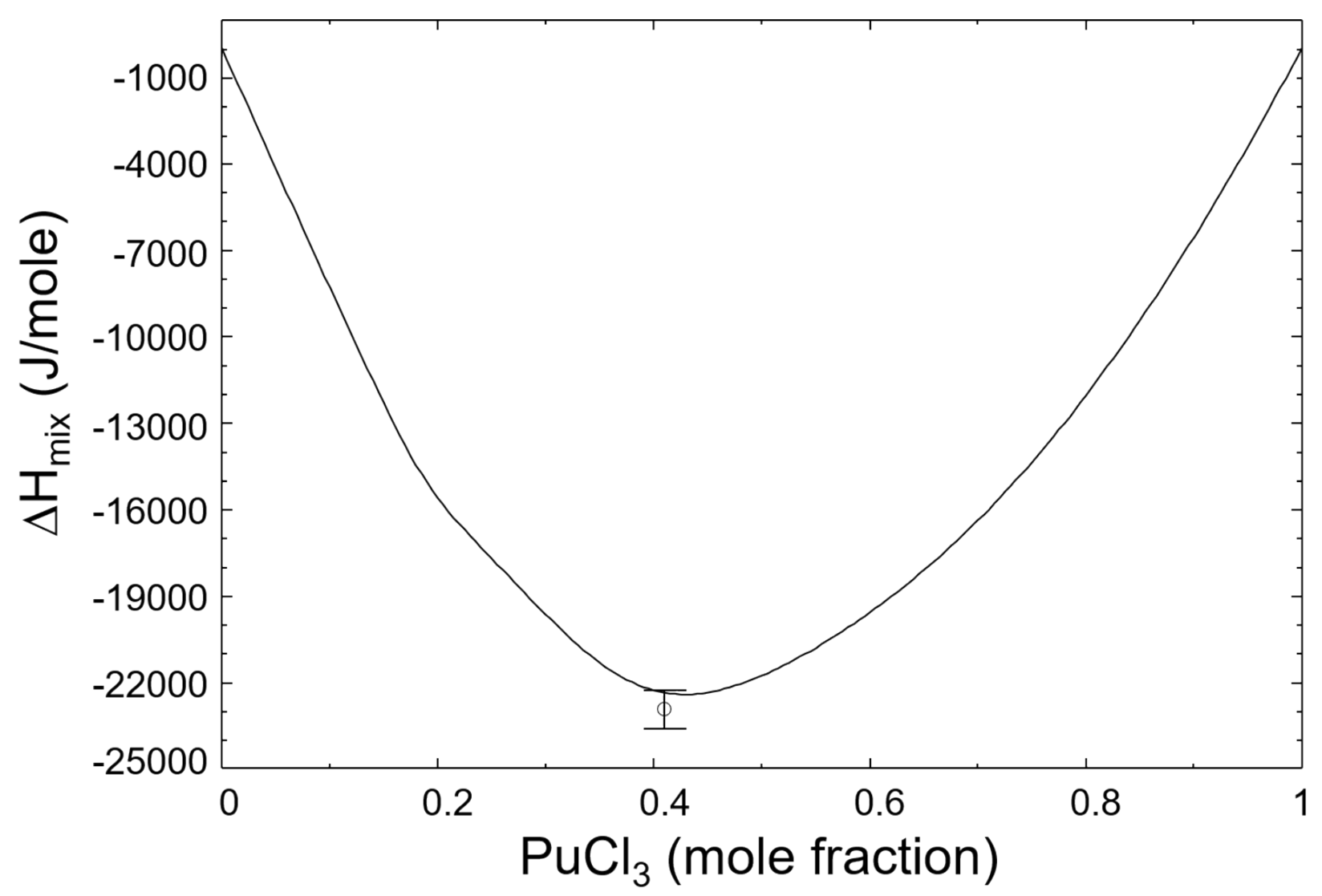

Figure 8. Calculated mixing enthalpy of system at $873.85^{\circ} \mathrm{C}$. Plotted data point from unpublished work.

\section{Summary and conclusions}

The MQM was successfully optimized to calculate an accurate phase diagram for the $\mathrm{CsCl}-\mathrm{PuCl}_{3}$ pseudobinary according to historical data and to replicate the estimated mixing enthalpy of the system. The use of two points of maximum SRO allowed for more control in the model, resulting in a better fit than that achievable using simpler models. This work should allow for more accurate extrapolation and modeling of related higher order systems and for inclusion of the assessment in the MSTDB-TC as the MQM is required and being used universally to represent the molten salt phase. The models from the assessments of the $\mathrm{NaCl}-\mathrm{AlCl}_{3}$ and $\mathrm{KCl}-\mathrm{AlCl}_{3}$ based on the work of Robelin et al. [30] were integrated into the MSTDB-TC. For the $\mathrm{BeF}_{2}-\mathrm{ZrF}_{4}$ system, optimization with multiple endmembers have shown success on reproducing the phase behavior around the miscibility gap, monotectic and $\mathrm{ZrF}_{4}$-rich compositions. However, model development focused on correcting the non-zero enthalpy of mixing of the endmembers in the MQM continues. Furthermore, the calculated eutectic and liquidus differs from the experimental phase diagram of Thoma [20]. These issues are planned to be resolved in FY22. 


\section{References}

[1] J. McMurray, K. Johnson, C. Agca, B. Betzler, D. Kropaczek, T. Besmann, D. Andersson, N.D. Ezell, Roadmap for thermal property measurements of Molten Salt Reactor systems, ORNL/SPR2020/1865, Oak Ridge, TN (United States), 2021. https://doi.org/10.2172/1778081.

[2] B.E. Poling, J.M. Prausnitz, J.P. O'Connell, Properties of Gases and Liquids, 5th Edition, McGraw-Hill Education, New York, 2001. https://doi.org/10.1036/0070116822.

[3] P. Chartrand, A.D. Pelton, Thermodynamic evaluation and optimization of the LiF-NaF-KF$\mathrm{MgF}_{2}-\mathrm{CaF}_{2}$ system using the modified quasi-chemical model, Metall. Mater. Trans. A. 32 (2001) 1385-1396. https://doi.org/10.1007/s11661-001-0228-1.

[4] U.R. Kattner, The thermodynamic modeling of multicomponent phase equilibria, JOM. 49 (1997) 14-19. https://doi.org/10.1007/s11837-997-0024-5.

[5] C.-A. Hwang, J.C. Holste, K.R. Hall, G. Ali Mansoori, A simple relation to predict or to correlate the excess functions of multicomponent mixtures, Fluid Phase Equilib. 62 (1991) 173-189.

https://doi.org/10.1016/0378-3812(91)80009-K.

[6] O. Redlich, A.T. Kister, Algebraic representation of thermodynamic properties and the classification of solutions, Ind. Eng. Chem. 40 (1948) 345-348.

[7] H.E.-S.M. El-Sayed, Viscosities and Densities of Some Multi- Component Regular Liquid Solutions at Different Temperature Levels, University of Windsor, 2010.

[8] G.N. Dul'nev, Y.P. Zarichnyak, Thermal conductivity of liquid mixtures, J. Eng. Phys. 11 (1966) 400-402. https://doi.org/10.1007/BF00829337.

[9] A.R. Mahajan, S.R. Mirgane, Excess Molar Volumes and Viscosities for the Binary Mixtures of nOctane, n-Decane, n-Dodecane, and n-Tetradecane with Octan-2-ol at 298.15 K, J. Thermodyn. 2013 (2013) 1-11. https://doi.org/10.1155/2013/571918.

[10] R.A. McAllister, The viscosity of liquid mixtures, AIChE J. 6 (1960) 427-431. https://doi.org/10.1002/aic.690060316.

[11] P.J. Spencer, A brief history of CALPHAD, Calphad. 32 (2008) 1-8. https://doi.org/https://doi.org/10.1016/j.calphad.2007.10.001.

[12] T.M. Besmann, J. Ard, S. Utlak, J.W. McMurray, R.A. Lefebvre, Status of the salt thermochemical database, Oak Ridge, TN (United States), 2019. https://doi.org/10.2172/1559647.

[13] A.D. Pelton, P. Chartrand, G. Eriksson, The modified quasi-chemical model: Part IV. Twosublattice quadruplet approximation, Metall. Mater. Trans. A. 32 (2001) 1409-1416. https://doi.org/10.1007/s11661-001-0230-7.

[14] J.W. McMurray, T.M. Besmann, J.C. Ard, S.A. Utlak, J.P. Lefebvre, Status of the molten salt thermodynamic database, 2019.

[15] A.D. Pelton, P. Chartrand, Thermodynamic evaluation and optimization of the LiCl-NaCl-KCl$\mathrm{RbCl}-\mathrm{CsCl}-\mathrm{MgCl}_{2}-\mathrm{CaCl}_{2}$ system using the modified quasi-chemical model, Metall. Mater. Trans. A. 32 (2001) 1361-1383. https://doi.org/10.1007/s11661-001-0227-2.

[16] O. Beneš, R.J.M. Konings, Thermodynamic evaluation of the $\mathrm{NaCl}-\mathrm{MgCl}_{2}-\mathrm{UCl}_{3}-\mathrm{PuCl}_{3}$ system, J. Nucl. Mater. 375 (2008) 202-208. https://doi.org/10.1016/j.jnucmat.2008.01.007.

[17] S. Cantor, Density and viscosity of several molten fluoride mixtures, Oak Ridge, TN (United States), 1973. https://doi.org/10.2172/4419855.

[18] O. Beneš, R.J.M. Konings, Thermodynamic study of $\mathrm{LiF}-\mathrm{BeF}_{2}-\mathrm{ZrF}_{4}-\mathrm{UF}_{4}$ system, J. Alloys Compd. 452 (2008) 110-115. https://doi.org/10.1016/j.jallcom.2007.01.184.

[19] Y.M. Korenev, A. V. Novoselova, An Investigation of $\mathrm{BeF}_{2}-\mathrm{ZrF}_{4}$ System, Dokl. Akad. Nauk SSSR. 149 (1963) 1337-1339.

[20] R.E. Thoma, H. Insley, H.A. Friedman, G.M. Hebert, Equilibrium phase diagram of the lithium fluoride-beryllium fluoridezirconium fluoride system, J. Nucl. Mater. 27 (1968) 166-180. https://doi.org/10.1016/0022-3115(68)90120-7.

[21] M. Poulain, Glass formation in ionic systems, Nature. 293 (1981) 279-280. 
https://doi.org/10.1038/293279a0.

[22] M. Poulain, M. Poulain, J. Lucas, Verres fluores au tetrafluorure de zirconium proprietes optiques d'un verre dope au Nd ${ }^{3+}$, Mater. Res. Bull. 10 (1975) 243-246. https://doi.org/10.1016/00255408(75)90106-3.

[23] C. Robelin, P. Chartrand, Thermodynamic evaluation and optimization of the $\left(\mathrm{NaF}+\mathrm{AlF}_{3}+\mathrm{CaF}_{2}+\mathrm{BeF}_{2}+\mathrm{Al}_{2} \mathrm{O}_{3}+\mathrm{BeO}\right)$ system, J. Chem. Thermodyn. 57 (2013) 387-403. https://doi.org/10.1016/j.jct.2012.09.005.

[24] C.W. Bale, P. Chartrand, S.A. Degterov, G. Eriksson, K. Hack, R. Ben Mahfoud, J. Melançon, A.D. Pelton, S. Petersen, FactSage thermochemical software and databases, Calphad. 26 (2002) 189-228. https://doi.org/10.1016/S0364-5916(02)00035-4.

[25] C.W. Bale, E. Bélisle, P. Chartrand, S.A. Decterov, G. Eriksson, A.E. Gheribi, K. Hack, I.-H. Jung, Y.-B. Kang, J. Melançon, A.D. Pelton, S. Petersen, C. Robelin, J. Sangster, P. Spencer, M.A. Van Ende, FactSage thermochemical software and databases, 2010-2016, Calphad. 54 (2016) 35-53. https://doi.org/10.1016/j.calphad.2016.05.002.

[26] A.R. Taylor, T.E. Gardner, Some Thermal Properties of Beryllium Fluoride from 80 to 1,200 K, US Department of the Interior, Bureau of Mines, Washington, D.C., 1965.

[27] D.M. ROY, R. ROY, E.F. OSBORN, Fluoride Model Systems: III, The System NaF-BeF 2 and the Polymorphism of $\mathrm{Na}_{2} \mathrm{BeF}_{4}$ and $\mathrm{BeF}_{2}$, J. Am. Ceram. Soc. 36 (1953) 185-190. https://doi.org/10.1111/j.1151-2916.1953.tb12864.x.

[28] A.D. Pelton, S.A. Degterov, G. Eriksson, C. Robelin, Y. Dessureault, The modified quasichemical model I-Binary solutions, Metall. Mater. Trans. B. 31 (2000) 651-659. https://doi.org/10.1007/s11663-000-0103-2.

[29] A.D. Pelton, P. Chartrand, The modified quasi-chemical model: Part II. Multicomponent solutions, Metall. Mater. Trans. A. 32 (2001) 1355-1360. https://doi.org/10.1007/s11661-001-0226-3.

[30] C. Robelin, P. Chartrand, A.D. Pelton, Thermodynamic evaluation and optimization of the $\left(\mathrm{NaCl}+\mathrm{KCl}+\mathrm{AlCl}_{3}\right)$ system, J. Chem. Thermodyn. 36 (2004) 683-699. https://doi.org/10.1016/j.jct.2004.04.011.

[31] M.W. Chase Jr, JANAF thermochemical table, J. Phys. Chem. Ref. Data. 14 (1985) SupplementNo.

[32] Scientific Group Thermodata Europe, SGPS, Pure Subst. Database. (n.d.). https://www.sgte.net/en/neu (accessed August 6, 2021).

[33] W. Fischer, A.-L. Simon, Über thermische Eigenschaften von Halogeniden. 15. Über das Schmelzdiagramm des Systems: $\mathrm{AlCl}_{3}-\mathrm{NaCl}-\mathrm{KCl}_{2}$ ) (mit Beobachtungen bei der Elektrolyse von Natrium-aluminium-chlorid-Schmelzen), Zeitschrift Für Anorg. Und Allg. Chemie. 306 (1960) 112. https://doi.org/10.1002/zaac.19603060102.

[34] R. Benz, R.M. Douglass, Phase Equilibria in The Binary Systems $\mathrm{PuCl}_{3}-\mathrm{RbCl}_{\text {and }} \mathrm{PuCl}_{3}-$ CsCl 1, J. Phys. Chem. 65 (1961) 1461-1463. https://doi.org/10.1021/j100826a515.

[35] E.M. Foltyn, R.N.R. Mulford, K.M. Axler, J.M. Espinoza, A.M. Murray, Thermodynamic modeling and experimental investigations of the $\mathrm{CsCl}-\mathrm{CaCl}_{2}-\mathrm{PuCl}_{3}$ system, J. Nucl. Mater. 178 (1991) 93-98. https://doi.org/10.1016/0022-3115(91)90459-K.

[36] M.A. Williamson, P.D. Kleinschmidt, Free energy of formation of $\mathrm{Cs}_{3} \mathrm{PuCl}_{6}$ and $\mathrm{CsPu}_{2} \mathrm{Cl}_{7}, \mathrm{~J}$. Nucl. Mater. 201 (1993) 115-119. https://doi.org/10.1016/0022-3115(93)90165-U.

[37] R.J. Lemire, J. Fuger, H. Nitsche, P. Potter, M.H. Rand, J. Rydberg, K. Spahiu, J.C. Sullivan, W.J. Ullmann, P. Vitorge, H. Wanner, Chemical Thermodynamics of Neptunium and Plutonium, Elsevier, Amsterdam, 2001.

[38] D.L. Clark, D.A. Geeson, R.J. Hanrahan, Plutonium Handbook, American Nuclear Society La Grange Park, Illinois, USA, 2019.

[39] I. Barin, O. Knacke, O. Kubaschewski, Thermochemical properties of inorganic substances, Springer Berlin Heidelberg, Berlin, Heidelberg, 1977. https://doi.org/10.1007/978-3-662-02293-1.

[40] J. Serp, R.J.. Konings, R. Malmbeck, J. Rebizant, C. Scheppler, J.-P. Glatz, Electrochemical behaviour of plutonium ion in LiCl-KCl eutectic melts, J. Electroanal. Chem. 561 (2004) 143- 
148. https://doi.org/10.1016/j.jelechem.2003.07.027.

[41] R. Guillaumont, T. Fangänel, V. Neck, J. Fuger, D.A. Palmer, I. Grenthe, M.H. Rand, Update on the chemical thermodynamics of uranium, neptunium, plutonium, americium and technetium, OECD Nuclear Energy Agency, Palaiseau, France, 2003. https://www.oecdnea.org/dbtdb/pubs/vol5-update-combo.pdf. 